\title{
Isolation, characterization and screening of PGPR capable of providing relief in salinity stress
}

\author{
Hina Javed a,*, Aneela Riaz a, Amjad Qureshi a , Komal Javed b, Fakhir Mujeeb a \\ Fraza Ijaz a, Muhammad Saleem Akhtar a, M. Asif Ali a, Rehman Gul c, Muhammad Aftab a \\ a Ayub Agriculture Research Institute, Faisalabad, Pakistan \\ b University of Agriculture, Faisalabad, Pakistan \\ c Soil and Water Testing Lab for Research, Lahore, Pakistan
}

\section{Article Info}

Received : 15.05.2019

Accepted : 05.11.2019

\begin{abstract}
Environmental stresses such as drought, temperature, salinity, air pollution, heavy metals, pesticides, and soil $\mathrm{pH}$ are major limiting factors in crop production because they affect almost all plant functions. Soil salinization is a serious stress condition causing major problem for crop productivity. To combat this salinity stress, Plant growth promoting rhizobacteria (PGPR) is considered as innovative, effective and ecofriendly approach. Plant growth promoting rhizobacteria (PGPR) have various direct and indirect mechanisms which can be correlated with their ability to form biofilms, chemotaxis, and the production of exopolysaccharide, indole-3-acetic acids (IAA) and aminocyclopropane-1- carboxylate (ACC) deaminase Investigations on the interaction of PGPR with other microbes and their effect on the physiological response of crop plants under different soil salinity regimes are still at an incipient stage. An experiment was conducted to investigate the effect of PGPR on lowering down the salt stress. Treatments were control $\left(\mathrm{T}_{1}\right)$, Salt tolerant isolate KH-1 $\left(\mathrm{T}_{2}\right)$, Salt tolerant isolate KH-2 $\left(\mathrm{T}_{3}\right)$, Salt tolerant isolate KH-3 ( $\left.\mathrm{T}_{4}\right)$, PGPR-I (Pseudimonas) $\left(\mathrm{T}_{5}\right)$, PGPR-II (Azotobacter) $\left(\mathrm{T}_{6}\right.$ ). Rice was sown under saline conditions at Soil Salinity Research Institute, Pindi Bhattian. With the inoculation of salt tolerant PGPR, plant growth and yield was improved. Result showed significant increase in plant height, biomass and yield over control. Inoculation of salt tolerant isolate $\mathrm{KH}-2$ produced maximum grain yield in rice (4267 kg/ha) followed by PGPR-II and it was statistically significant from all other treatments along with control. It is concluded that with the application of salt tolerant isolate (KH-2), there is significant increase in rice production.

Keywords: PGPR, abiotic stresses, Azotobacter, Pseudomonas, auxin production.
\end{abstract}

(c) 2020 Federation of Eurasian Soil Science Societies. All rights reserved

\section{Introduction}

Due to salt stress agricultural productivity has been decreased all over the world (Jouyban, 2012). According to an estimate about $20 \%$ of all irrigated and cultivated lands (equivalent to 62 million ha) are negatively affected by salt stress at present time (Khan et al., 2015). In arid and semiarid regions salinity is considered as major hurdle to plant growth and productivity. About $831 \mathrm{mha}$ of land is affected by salt all over the world (FAO, 2008). Agriculture has very special place in Pakistan's economy. Irrigated agriculture in Pakistan is facing the problem of water-logging and salinity therefore productive lands are continuously going out of cultivation (Chaudhary, 2001). The limited rainfall, high evapotranspiration rate and high temperature are the major causes of salinity in arid and semiarid regions (Neto et al., 2006). The occurrence of physiological and molecular disorders due to salinity is under consideration since many years but the actual process is still unknown (Hasegawa et al., 2000). Due to salinity, synthesis of lipids and protein along with photosynthesis are badly affected in plants (Parida and Das, 2005).

Soil salinity is considered as great threat all over the world that affects nearly one billion hectare land and has an adverse effect on crop production of productive lands (Rengasamy, 2006) and considered as a major

${ }^{*}$ Corresponding author.

Ayub Agriculture Research Institute, P/239 Street No. 5 Ahmadabad, Faisalabad, Pakistan

Tel.: +923336580868

E-mail address: hina_javed_2102@yahoo.com e-ISSN: 2147-4249

DOI: $10.18393 /$ ejss.650546 
challenge to farmers (Flowers and Flowers, 2005). In irrigated areas this problem is more dominant (Flowers, 1999; Zhu, 2001) that is major cause in loss of food production (Munns and Tester, 2008). There is also problem of salinity in dry land regions (Wang et al., 1993; Rengasamy, 2006). In saline condition more salts are present in soils. $\mathrm{NaCl}$ is the most dominant in salt effected soils (Zhang et al., 2010).

Due to salinity uptake and translocation of $\mathrm{Na}^{+}$and $\mathrm{K}^{+}$is affected which results in poor plant growth and metabolism through reduced uptake, nutritional imbalance and toxic effect of some ions. (Nawaz et al., 2002; Tavakkoli et al., 2010). The increased uptake of $\mathrm{K}$ results in decreased uptake of $\mathrm{K}$ and Ca (Marschner, 1995; Yildirim et al., 2006). The nitrate reductase activity is inhibited by accumulation and uptake of $\mathrm{Cl}^{-}$which in return greatly disturb the photosynthetic activity of plant (Tavakkoli et al., 2000). Salts get accumulated in the intercellular spaces when the capacity of cell to store a specific concentration of salt is exceeded and results in cell dehydration which eventually lead to cell death (Sheldon et al., 2004).

Salinity causes a number of biochemical and physiological changes in plant cells that lead to stress symptoms on plants and ultimately reduce growth and development of whole plant (Huang et al., 2012). Plants have different mechanisms to tolerate salinity which includes compartmentation of inorganic ions, adjustment in osmotic balance and reduction in leaf osmotic potential by synthesis of organic solutes etc (Hasegawa et al., 2000).

The use of PGPR is one approach to solve the issue of salinity. Different plant growth promoting rhizobacteria (PGPR) residing near the roots of plants have been reported to provide beneficial effects by different direct and indirect processes. These bacteria have ability to combat salinity stress by different mechanisms which include production of indole-3-acetic acid (IAA), production of ACC-deaminase, solubilization of phosphorus, exopolysaccharide production, production of volatile compounds etc. Auxin (IAA) production by PGPR which stimulates the production of flavonoids by plants, improves nitrogen fixation, nodulation and nutrient uptake which in turn reduced the harmful effects caused by salinity (Dodd and Pérez-Alfocea, 2012). Ethylene act as inhibitor when released during stress by plants and causes reduction in legume's nodulation. In plants the pathway of production of ethylene is Yang cycle in which ACC oxidase enzyme is responsible for the conversion of ACC into ethylene (Tilak et al., 2005). Plant growth promoting rhizobacteria (PGPR) have ability to produce enzyme 1-aminocyclopropane-1-carboxylic acid deaminase (ACC-D), which is actually a precursor of ethylene and reduces the level of ethylene during salt stress (Glick, 2014; Choudhary et al., 2015). The AAC deaminase producing PGPR attached to the root of plants and uptake ACC which is released from plant roots and then hydrolyze it (Glick et al., 1998.) Many scientist have reported in reduction of salinity stress through ACC-D containing PGPR and thus improve plant growth (Glick, 2010; Ahmed and Farag 2011).

Microbial secreted exopolysaccharides (EPS) are responsible for chelation of surplus ions and decreases the availability of these ions ( $\left.\mathrm{Na}^{+}\right)$to plants. (Choudhary et al., 2015). PGPR are responsible to solubilize the insoluble nutrients like iron, zinc, potassium and phosphorus by secreting organic acids in the rhizosphere which in turn increases the uptake of nutrients by plants. One novel approach of PGPR is the production of VOCs (Volatile Organic Compounds) which are responsible for signalling between plant and microbe. Specific strains of bacteria releases volatile compounds increased the growth of plants by variable processes like osmoprotectant biosynthesis, nutrient uptake, hormone distribution and sodium homeostasis (Singh et al., 2008; Liu and Zhang, 2015). Mitigation of salinity by PGPR inoculants has been shown in rice, wheat, maize, cotton, lettuce, tomato and pepper (da Costa et al., 1998, Bacilio et al., 2004; Parida and Das 2005).

Pakistan is the world's $11^{\text {th }}$ largest producer of rice. Pakistan's exports make up $8 \%$ of world's total rice trade. It is an important crop in the agriculture economy of Pakistan. Rice is an important Kharif crop. In the year 2016/17, Pakistan produced 6.7 million tonnes, of which around 4 million were exported, mainly to neighbouring countries, the Middle East and Africa. Rice is grown in fertile lands of Sindh and Punjab region where millions of farmers rely on rice cultivation as their major source of employment. Among the most famous varieties grown in Pakistan include the Basmati, known for its flavour and quality. Pakistan is a major producer of this variety.

The objective of this research is the isolation and characterization of salt tolerant PGPR from salt affected areas. Based on IAA production and their growth promotion abilities, selected bacterial isolates were tested for growth and production of rice under salinity conditions in field experiment.

\section{Material and Methods}

\section{Isolation of salt tolerant bacteria}

Soil samples were collected from Kheura salt mines situated in Pind Dadan Khan and its nearby areas from rhizosphere of different plants. Samples were shifted to lab and store under cold condition $\left(4{ }^{\circ} \mathrm{C}\right)$ for further proceedings. Salt tolerant bacteria (STB) were isolated from dilution plate technique on LB medium 
(Tryptophane; $10, \mathrm{NaCl} ; 10$, Yeast; 5, Agar; 20g/L). From the preserved soil samples, one gram of soil was weighed and different dilutions were made. Dilutions were spread on petri plates containing LB agar medium and incubated at $28 \pm 2{ }^{\circ} \mathrm{C}$. After growth of bacterial colonies, the isolates having glycery and proliferating growth were frequently streak on LB medium to get purified colonies. Isolated colonies were preserved at $-40^{\circ} \mathrm{C}$ in glycerol solution.

\section{Characterization of selected isolates}

Selected bacterial isolates were characterized for IAA production activity (Sarwar et al., 1992). To diagnose the bacterial auxin production the method of Sarwar et al. (1992) was followed. For this $25 \mathrm{~mL}$ of General Purpose Media (GPM) media was autoclaved and cooled and inject with bacterial isolates @ $1 \mathrm{~mL} / \mathrm{flask}$. The solution was incubated ( $28 \pm 1 \circ \mathrm{C}$ for 48 hours) and filtered through Whatman No. 2 . The filtrate (3ml) was taken and $2 \mathrm{ml}$ Salkowski's reagent $\left(98 \mathrm{~mL}\right.$ of $35 \% \mathrm{HClO}_{4}+2.0 \mathrm{~mL}$ of $0.5 \mathrm{M} \mathrm{FeCl}_{3}$ ) was added. The samples were run on spectrophotometer at $535 \mathrm{~nm}$ wavelength. An un-inoculated control with GPM broth was also prepared for comparison.

\section{Screening of bacteria for plant growth promotion activities under controlled conditions}

An experiment was planned in growth room to check the efficiency of bacteria for growth promotion under normal and controlled condition (Temp $30-35^{\circ} \mathrm{C}$ ). A pot experiment was conducted in the growth room of Soil Bacteriology Section, AARI, Faisalabad, Pakistan. Ten pre isolated salt tolerant isolates were used to check microbial effect on rice growth. Growth parameters were studied after 10 days of seed germination. On the basis of growth parameters (Root and shoot length, and dry biomass), 3 best growth promoting bacterial isolates were selected for further study. Two pre isolated isolates PGPR-I (Pseudomonas) and PGPR-II (Azotobacter) were also used in this experiment. Completely randomized design (CRD) was used for this experiment.

\section{Field Experiment}

Field experiment on rice was conducted at the Soil Salinity Research Institute, Pindi Bhattian having EC=06. The main objective of this study was to analyze the effectiveness of salt tolerant bacteria on growth and yield parameters by adaptations against the salt stress conditions on field level. Rice variety Super Basmati was used for the experiment. The statistical design was randomized complete block design (RCBD) having three replicates. Treatments were $\mathrm{T}_{1}=$ control, $\mathrm{T}_{2}=\mathrm{KH}-1, \mathrm{~T}_{3}=\mathrm{KH}-2, \mathrm{~T}_{4}=\mathrm{KH}-3, \mathrm{~T}_{5}=\mathrm{PGPR} \mathrm{I}$ (Pseudomonas) and $\mathrm{T}_{6}=$ PGPR II (Azotobacter).

\section{Statistical Analysis}

The analysis of data was done by using analysis of variance technique (ANOVA) with RCBD (Steel et al., 1997). For this purpose, software Statistix 8.1 was used and arithmetic means were compared by using least significant difference (LSD) test.

\section{Results}

The present study was conducted to discover the efficiency of salt tolerant bacteria as suppressor of the salt stresses.

\section{Isolation, screening and characterization of salt tolerant bacteria (STB)}

The salt tolerant bacteria were isolated from different plant rhizosphere by using dilution plate technique on LB media. Total 20 isolates were isolated from rhizosphere and characterized on the basis of auxin production. Ten isolates were carefully chosen and screened on growth promotion basis through bioassay in lab and three promising isolates wee then selected on the basis of maximum root/shoot elongation. These three isolates along with two pre-isolated PGPR were tested in field conditions having highly saline soils.

\section{Auxin production $\left(\mu \mathrm{g} \mathrm{mL} \mathbf{~}^{-1}\right)$}

Data expressed the potential of various isolates to produce auxin (as IAA equivalents). The data related to auxin production is presented in Table 1 . All isolates produced auxin in broth culture. The maximum auxin production as IAA equivalents was recorded in $\mathrm{KH}-1$ bacterial isolate $\left(13 \mu \mathrm{g} \mathrm{mL}^{-1}\right)$ followed by KH-2 and KH$3\left(11.8 \mu \mathrm{g} \mathrm{mL}^{-1}\right)$ and it was statistically different from control. The IAA produced by bacterial isolates could be useful with plants especially when interacted with plant exudates that may help the IAA production potential of the bacteria (Harrison et al., 2002; Rani et al., 2012).

Table 1. Auxin level of different isolate

\begin{tabular}{|c|c|c|c|c|c|}
\hline Isolates & Auxin $\left(\mu \mathrm{g} \mathrm{mL}^{-1}\right)$ & Isolates & Auxin ( $\left.\mu \mathrm{g} \mathrm{mL}^{-1}\right)$ & Isolates & Auxin $\left(\mu g \mathrm{~mL}^{-1}\right)$ \\
\hline Control & $2.8 \mathrm{j}$ & KH-7 & 5.8 fghi & $\mathrm{KH}-14$ & $10.0 \mathrm{bc}$ \\
\hline KH-1 & 13.0 & KH-8 & cde & $\mathrm{KH}-15$ & 4.1 \\
\hline $\mathrm{KH}-2$ & $11.8 \mathrm{ab}$ & KH-9 & cdef & $\mathrm{KH}-16$ & cde \\
\hline $\mathrm{KH}-3$ & 11.8 & KH-10 & fgh & KH-17 & 9.5 \\
\hline $\mathrm{KH}-4$ & ghij & KH-11 & def & KH-18 & bcd \\
\hline KH-5 & efg & $\mathrm{KH}-12$ & ghij & KH-19 & fgh \\
\hline КH-6 & 3.8 & KH-13 & 6.9 & $\mathrm{KH}-20$ & def \\
\hline
\end{tabular}




\section{Screening of bacteria for plant growth promotion activity through bioassay}

Data regarding shoot/root length and biomass are shown in Table 2. The inoculation of bacterial isolates in abiotic stress conditions showed positive response on growth. Maximum shoot length $(40.7 \mathrm{~cm})$ was observed in isolate KH-1 and showed significant difference statistically from control. The root length, shoot fresh biomass and root fresh biomass was also showed higher response upon inoculation as compared to control. Among the bacterial isolates $\mathrm{KH}-10$ showed minimum response towards inoculation. The improvement in plant physical parameters may be the result of production of different plant growth regulators and siderophores (Kloepper et al., 1989; Arshad and Frankenberger Jr., 1998).

Table 2. Effect of STB on growth parameters

\begin{tabular}{|c|c|c|c|c|}
\hline Isolates & Shoot Length (cm) & Root length (cm) & Shoot fresh biomass (g) & Root fresh biomass (g) \\
\hline Control & $28.6 \mathrm{~d}$ & $25.6 \mathrm{e}$ & $2.31 \mathrm{de}$ & $2.45 \mathrm{de}$ \\
\hline $\mathrm{KH}-1$ & 40.7 & 45.9 & 3.98 & 4.49 \\
\hline КH-2 & 38.4 & 32.4 & 3.24 & 3.98 \\
\hline KH-3 & 32.4 & 39.8 & 3.12 & 4.24 \\
\hline KH-14 & 39.6 & 29.6 & 2.56 & 3.14 \\
\hline KH-18 & 35.4 & 28.4 & 2.35 & 3.56 \\
\hline KH-17 & 36.4 & 41.5 & 3.39 & 3.32 \\
\hline KH-16 & 34.2 & 32.5 & 3.56 & 3.28 \\
\hline KH-8 & 39.6 & 36.7 & 3.48 & 3.92 \\
\hline KH-9 & 37.6 & 35.9 & 2.98 & 3.52 \\
\hline KH-11 & 32.3 & 33.9 & 3.48 & 3.21 \\
\hline
\end{tabular}

\section{Yield parameters}

Data of field trial showed that with the inoculation of salt tolerant PGPR plant growth and yield was significantly improved. Result showed that bacterial inoculation significantly enhanced the plant height, biomass, yield and no. of tillers over control.

\section{Plant Height}

According to the results (Figure 1) plant height was increased upon inoculation over control and maximum $(132.7 \mathrm{~cm})$ was observed in case of $\mathrm{KH}-2$ inoculation.

As compare to control $(110.0 \mathrm{~cm})$ plant height was increased in all other treatments. In case of PGPR II (Azotobacter) inoculation plant height was more $(127.7 \mathrm{~cm})$ as compared to PGPR I (Pseudomonas) inoculation $(121.0 \mathrm{~cm})$. Similarly in case of $\mathrm{KH}-1$ plant height was more $(124.3 \mathrm{~cm})$ as compared to $\mathrm{KH}-3(121.7 \mathrm{~cm})$. But in case of $\mathrm{KH}-2$ plant height was maximum $(132.7 \mathrm{~cm})$. So, $\mathrm{KH}-2$ showed the more pronounced response as compare to all other treatments. In case of salt tolerant bacteria KH-2 showed better response and in case of PGPR II (Azotobacter) showed better results.

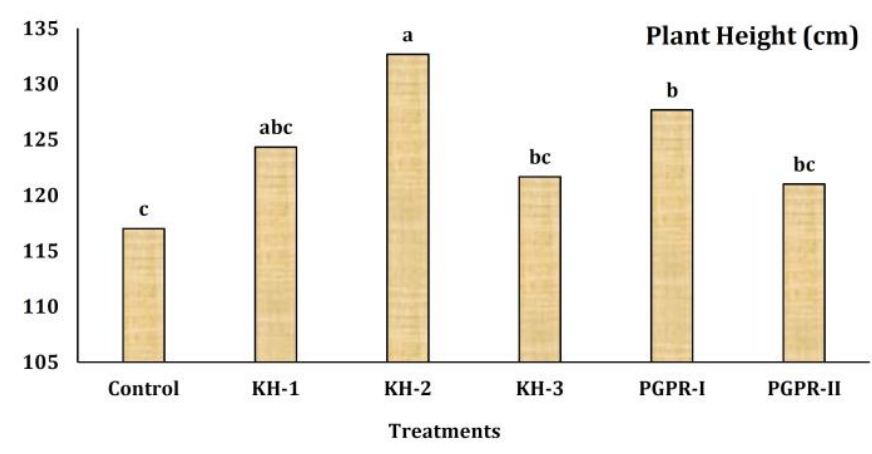

Figure 1. Effect of salt tolerant isolates and rhizobacteria on plant height of rice at SSRI, Pindi Bhattian

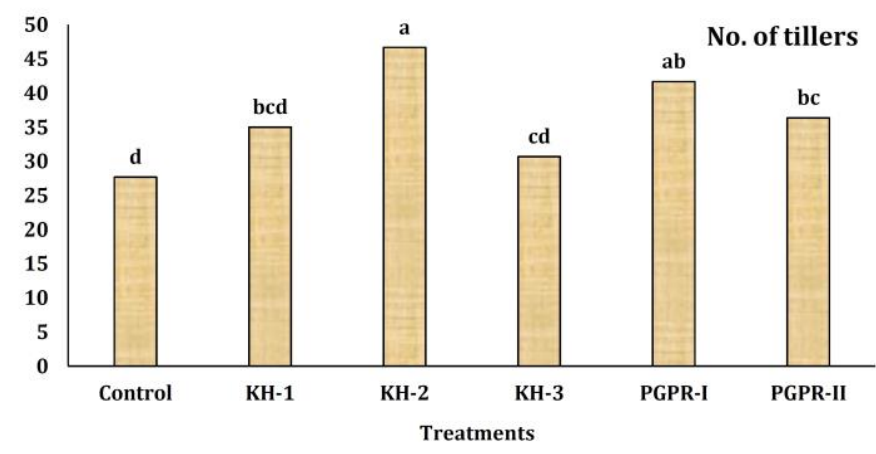

Figure 2. Effect of salt tolerant isolates and rhizobacteria on tillers $/ \mathrm{m} 2$ in rice at SSRI, Pindi Bhattian 


\section{Straw Yield}

Straw yield of rice was increased by the inoculation of salt tolerant bacteria and PGPR (Figure 3). In case of salt tolerant bacteria maximum straw yield was found by KH-2 (13.83 t/ha) as compare to KH1 (12.61 t/ha) and KH-3 (12.25 t/ha). In case of PGPR II (Azotobacter) and PGPR I (Pseudomonas) inoculation trend in straw yield 12.81 and 12.20 t/ha respectively.

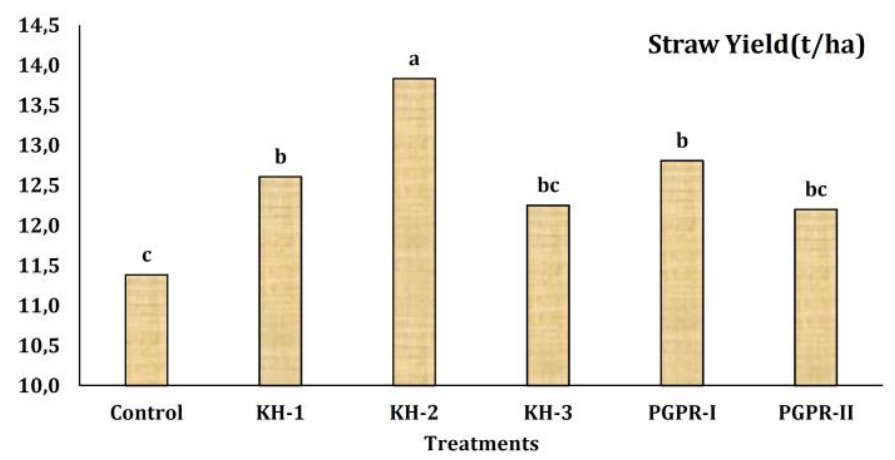

Figure 3. Effect of salt tolerant isolates and rhizobacteria on rice paddy yield at SSRI, Pindi Bhattian

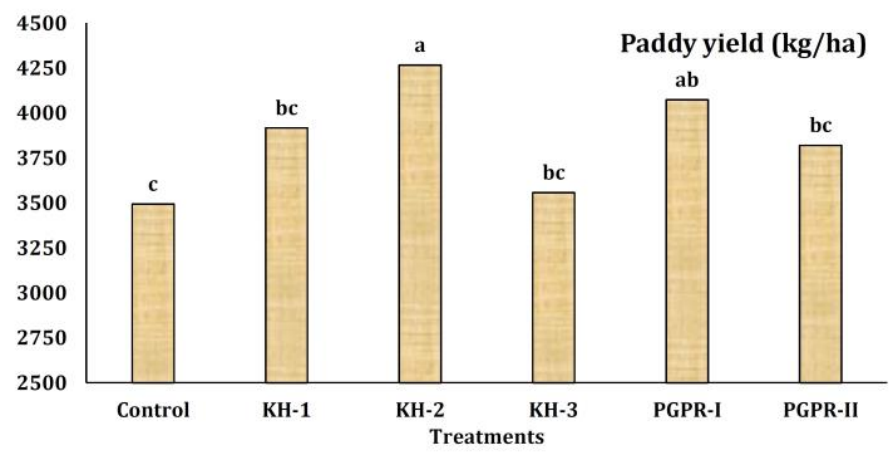

Figure 4. Effect of salt tolerant isolates and rhizobacteria on rice paddy yield at SSRI, Pindi Bhattian

\section{Discussion}

Salinity is one of the major problem that badly affects the health of plants and then decreases crop productivity. Plants itself have various defense mechanisms against salt stress but other soil-plant factors also have robust impact on salinity tolerance. One mechanism offered by soil is the presence of soil beneficial bacteria called PGPR possessing different direct and indirect effects to combat salinity. In the present study salt tolerant bacteria were isolated from the rhizospheric soil of different salt prone areas (Kheura mines and their surroundings). Then these bacteria were characterized on the basis of IAA production. Then lab study was conducted to screen out growth promoting abilities of PGPR. After that field trial was conducted at SSRI, Pindi Bhattian on rice. According to the results with the application of salt tolerant bacteria grain yield of rice was improved. They also have positive effect on the physical growth and other parameters of wheat and rice. Our results are related to the work of many other scientists in the literature.

PGPR have different pathways to ameliorate salts from the vicinity of plants. One mechanism is to produce compatible solutes including amino acids, sugars or their derivatives that act as osmolytes and in this way organism can survive the extreme salt conditions (Bacilio et al., 2004; da Costa et al., 1998; Parida and Das, 2005). The other bacterial traits like P-solubilization, auxin production, nutrients availability results in improved growth and yield of crop plants (Glick, 2010). The improvement in plant physical parameters may be the result of production of different plant growth regulators and siderophores (Kloepper et al., 1989; Arshad and Frankenberger Jr. 1998). Additionally, Tilak et al. (2005) suggest that those bacteria which are present in salt prone areas and isolate from those rhizospheres have natural ability to tolerate salinity. The IAA produced by bacterial isolates could be useful with plants especially when interacted with plant exudates that may help the IAA production potential of the bacteria. According to Usha et al., 2012 the most important signal molecule in the regulation of plant development is auxinl. Phosphorus is typically insoluble or poorly soluble in soils under salt stressed conditions and these PGPR helps in the solubilization of insoluble P and thus improve plant growth and development (Harrison et al., 2002; Glick, 2010). In another study carried out by Zhang et al. (2010) reported that through regulation of the potassium transporter HKT1 could reduce the bad effects of salinity which is induced by the inoculation of Bacillus subtilis GB03 in Arabidopsis thaliana (Hichem et al., 2009; Jeong et al., 2011). Oxidative damage caused by salinity can be reduced through synthesis of polyphenols by plants (Hichem et al., 2009; Nounjan et al., 2012, Amin et al., 
2016). Co-inoculation of PGPR with Rhizobium improved plant dry matter significantly upon control (Rahman et al., 2016). Similar findings were reported by Qureshi et al. (2011) who observed a significant increase in concentration of nutrients in grains and other parts of plants by co-inoculation of Bacillus and Rhizobium in a pot experiment.

\section{Conclusion}

All the bacterial isolates showed high resistance to salinity stress. All the bacterial isolates showed significant improvement in plant growth parameters as compared to control. Among the salt tolerant isolates (KH-1, KH-2, KH-3), KH-2 performed better followed by PGPR II (Azotobacter). The grain yield of rice was also significantly increased by these two treatments over other treatments as well as control.

\section{References}

Ahmed, H.M.I., Farag, M.M.A., 2011. Alleviation of salinity stress in lettuce during germination by seed priming. Journal of Plant Production - Mansoura University 2(5): 725-737

Amin, U.S.M., Biswas, S., Elias, S.M., Razzaque, S., Haque, T., Malo, R., Seraj, Z.I., 2016. Enhanced salt tolerance conferred by the complete $2.3 \mathrm{~kb}$ cDNA of the rice vacuolar $\mathrm{Na}+/ \mathrm{H}+$ antiporter gene compared to $1.9 \mathrm{~kb}$ coding region with $5^{\prime}$ UTR in transgenic lines of rice. Frontiers in Plant Science 7: 14.

Arshad, M., Frankenberger Jr., W.T., 1998. Plant growth-regulating substances in the rhizosphere: Microbial production and functions. Advances in Agronomy 62: 45-151.

Bacilio, M., Rodriguez, H., Moreno, M., Hernandez, J.P., Bashan, Y., 2004. Mitigation of salt stress in wheat seedlings by a gfp-tagged Azospirillum lipoferum. Biology and Fertility of Soils 40(3) 188-193.

Chaudhary, M.R. 2001. Gypsum efficiency in the amelioration of saline sodic/sodic soils. International Journal of Agriculture and Biology 3(3):276-280.

Choudhary, D.K., Kasotia, A., Jain, S., Vaishnav, A., Kumari, S., Sharma, K.P., Varma, A., 2015. Bacterial-mediated tolerance and resistance to plants under abiotic and biotic stresses. Journal of Plant Growth Regulation 35(1): 276-300.

da Costa, M., H. Santos and E. Galinski. 1998. An overview of the role and diversity of compatible solutes in Bacteria and Archaea. In: Biotechnology of Extremophiles. Antranikian, G. (Ed.). Springer, Volume 61, pp. 117-153.

Dodd, I.C., Pérez-Alfocea, F., 2012. Microbial amelioration of crop salinity stress Journal of Experimental Botany 63(9): 3415-3428.

FAO, 2008. Global network on integrated soil management for sustainable use of salt-affected soils. Food and Agriculture Organization of the United Nations, Land and Plant Nutrition Management Service, Rome, Italy.

Flowers, T.J., 1999. Salinisation and horticultural production. Scientia Horticulturae (Amsterdam) 78: 1-4.

Flowers, T.J., Flowers, S.A., 2005. Why does salinity pose such a difficult problem for plant breeders? Agricultural Water Management 78(1-2): 15-24.

Glick, B.R, Penrose, D.M., Li, J., 1998. A model for the lowering of plant ethylene concentrations by plant growthpromoting bacteria. Journal of Theoretical Biology 190(1): 63-68.

Glick, B.R., 2010. Using soil bacteria to facilitate phytoremediation. Biotechnology Advances 28(3): 367-374.

Glick, B.R., 2014. Bacteria with ACC deaminase can promote plant growth and help to feed the world. Microbiological Research 169(1):30-39.

Harrison, M.J., Dewbre, G.R., Liu, J., 2002. A phosphate transporter from medicago truncatula involved in the acquisition of phosphate released by arbuscular mycorrhizal fungi. The Plant Cell 14: 2413-2429.

Hasegawa, P.M., Bressan, R.A., Zhu, J.K., Bohnert, H.J., 2000. Plant cellular and molecular responses to high salinity. Annual Review of Plant Physiology and Plant Molecular Biology 51: 463-499.

Hichem, H., El Naceur, A., Mounir, D., 2009. Effects of salt stress on photosynthesis, PSII photochemistry and thermal energy dissipation in leaves of two corn (Zea mays L.) varieties. Photosynthetica 47(4): 517-526.

Huang, G.T., Ma, S.L., Bai, L.P., Zhang, L., Ma, H., Jia, P., Liu, J., Zhong, M., Guo, Z.F., 2012. Signal transduction during cold, salt, and drought stresses in plants. Molecular Biology Reports 39(2): 969-987.

Jeong, J.S., Kim, Y.S., Baek, K.H., Jung, H., Ha, S.H., Do Choi, Y., Kim, M., Reuzeau, C., Kim, J.K., 2010. Root-specific expression of OsNAC10 improves drought tolerance and grain yield in rice under field drought conditions. Plant Physiology 153(1): 185-197.

Jouyban, Z., 2012. The effects of salt stress on plant growth. Technical Journal of Engineering and Applied Sciences 2(1): 7-10.

Khan, K., Agarwal, P., Shanware, A., Sane, V.A., 2015. Heterologous expression of two Jatropha Aquaporins imparts drought and salt tolerance and improves seed viability in transgenic Arabidopsis thaliana. PLoS One 10(6): e0128866.

Kloepper, J.W., Lifshitz, R., Zablotowicz, R.M., 1989. Free-living bacterial inocula for enhancing crop productivity. Trends in Biotechnology 7(2): 39-43.

Liu, X.M., Zhang, H., 2015. The effects of bacterial volatile emissions on plant abiotic stress tolerance. Frontiers in Plant Science 6: 774 .

Marschner, H., 1995. Mineral nutrition of higher plants. London: Academic Press. 889p.

Munns, R., Tester, M., 2008. Mechanisms of salinity tolerance. Annual Review of Plant Biology 59: 651-681. 
Nawaz, S. Akhtar, N. Aslam, M. Qureshi, R.H., Akhtar, J., 2002. Anatomical, morphological and physiological changes in sunflower varieties because of $\mathrm{NaCl}$ salinity. Pakistan Journal of Soil Science 21:87-93.

Neto, A.A.D., Prisco, J.T., Enéas-Filho, J., Abreu, C.E.B., Gomes-Filho, E., 2006. Effect of salt stress on antioxidative enzymes and lipid peroxidation in leaves and roots of salt-tolerant and salt-sensitive maize genotypes. Environmental and Experimental Botany 56(1): 87-94.

Nounjan, N., Nghia, P.T., Theerakulpisut, P., 2012. Exogenous proline and trehalose promote recovery of rice seedlings from salt-stress and differentially modulate antioxidant enzymes and expression of related genes. Journal of Plant Physiology 169(6): 596-604.

Parida, A.K., Das, A.B., 2005. Salt tolerance and salinity effects on plants: a review. Ecotoxicology and Environmental Safety 60(3): 324-349.

Qureshi, M.A., Shakir, M.A., Iqbal, A., Akhtar, N., Khan, A., 2011. Co-inoculation of phosphate solubilizing bacteria and rhizobia for improving growth and yield of mungbean (Vigna radiata L.). Journal of Animal and Plant Sciences 21(3): 491-497.

Rahman, M.A., Thomson, M.J., Shah-E-Alam, M., de Ocampo, M., Egdane, J., Ismail, A.M., 2016. Exploring novel genetic sources of salinity tolerance in rice through molecular and physiological characterization. Annals of Botany 117(6): 1083-1097.

Rani, M.U., Arundhathi, A., Reddy, G., 2012. Screening of rhizobacteria containing plant growth promoting (PGPR) traits in rhizosphere soils and their role in enhancing growth of pigeon pea. African Journal of Biotechnology 11(32): 8085-8091.

Rengasamy, P., 2006. World salinization with emphasis on Australia. Journal of Experimental Botany 57(5): 1017-1023.

Sarwar, M., Arshad, M., Martins, D.A., Frankenberger Jr, W.T., 1992. Tryptophan-dependent biosynthesis of auxins in soil. Plant and Soil 147(2): 207-215.

Sheldon, A., Menzies, N.W., Bing, S.H., Dalal, R.C., 2004. The effect of salinity on plant available water. Supersoil 2004: 3rd Australian/New Zealand Soils Conference. 5 - 9 December 2004. Sydney, Australia. Available at [access date: 19.02.2019]: http://www.regional.org.au/au/asssi/supersoil2004/s6/poster/1523_sheldona.htm

Singh, A.L., Hariprassanal, K., Solanki, R.M., 2008. Screening and selection of groundnut genotypes for tolerance of soil salinity. Australian Journal of Crop Science 1(3):69-77.

Steel, R.G.D., Torrie, J.H., Dickey, D.A., 1997. Principles and procedures of statistics: a biometrical approach. 3rd ed. McGraw-Hill, New York, USA. 666p.

Tavakkoli, E., Rengasamy, P., McDonald, G.K., 2010. High concentrations of $\mathrm{Na}+$ and $\mathrm{Cl}-$ ions in soil solution have simultaneous detrimental effects on growth of fava bean under salinity stress. Journal of Experimental Botany 61(15): 4449-4459.

Tilak, K.V.B.R., Ranganayaki, N., Pal, K.K., De, R., Saxena, A.K., Nautiyal, C.S., Mittal, S., Tripathi, A.K., Johri, B.N., 2005. Diversity of plant growth and soil health-supporting bacteria. Current Science 89(1): 136-150.

Wang, M.Y., Siddiqi, M.Y., Ruth, T.J., Glass, A.D.M., 1993. Ammonium uptake by rice roots (I. Fluxes and subcellular distribution of $13 \mathrm{NH}_{4}^{+}$). Plant Physiology 103: 1249-1258.

Yildirim, E., Taylor, A.G., Spittler, T.D., 2006. Ameliorative effects of biological treatments on growth of squash plants under salt stress. Scientia Horticulturae 111(1): 1-6.

Zhang, J.L., Flowers, T.J., Wang, S.M., 2010. Mechanisms of sodium uptake by roots of higher plants. Plant and Soil 326: 45-60.

Zhu, J.K., 2001. Plant salt tolerance. Trends in Plant Science 6(2): 66-71. 